\title{
Humboldtian Medicine
}

\author{
NICOLAAS A RUPKE*
}

\section{Medical Geography - the Secondary Literature}

Medical geography - the study of the global distribution of human diseases as a function of environmental conditions-was a largely nineteenth-century preoccupation. It incorporated the earlier and contemporaneously continuing interest of medical topography - the description of the medical conditions of particular places. Victorian medical geographers cited J F Cartheuser's De morbis endemiis libellus (1771) as the starting point of their subject; but George Rosen has argued that the first comprehensive medical geography was the Versuch einer allgemeinen medicinisch-praktischen Geographie (vols 1, 2: 1792; vol. 3: 1795), written by the German obstetrician and district medical officer ("Landphysicus") Leonhard Ludwig Finke. ${ }^{1}$

Major treatises on medical geography appeared over a period of approximately one hundred years, until by the end of the nineteenth century interest in environmental causes of diseases declined, as the development of bacteriology shifted aetiological thinking towards the germ-theory of infectious diseases. One of the greatest representatives of medical geography, to whom Frederick Sargent II has drawn attention, ${ }^{2}$ was another German, August Hirsch, whose massive, two-volume Handbuch der historischgeographischen Pathologie (vol. 1: 1860; vol. 2: 1862-64) went through a second, threevolume edition (vol. 1: 1881; vol. 2: 1883; vol. 3: 1886), which was translated into English under the auspices of the New Sydenham Society. ${ }^{3}$ Hirsch was active also as a historian of medicine: in addition to editing the Biographisches Lexikon der hervorragenden Ärzte aller Zeiten und Völker, he wrote the Geschichte der medizinischen Wissenschaften in Deutschland (1893). In this textbook, he briefly discussed medical geography, depicting its history as a straight line of development from Finke's Versuch to the second edition of his own Handbuch; on this line a few intervening contributions by other medical

*Nicolaas A Rupke, Institute for the History of Medicine, Göttingen University, Humboldtallee 36, 37073 Göttingen, Germany.

1 G Rosen, 'Leonhard Ludwig Finke and the first medical geography', in E A Underwood (ed.), Science, medicine and history: essays on the evolution of scientific thought and medical practice, written in honour of Charles Singer, London, New York, Toronto, Oxford University Press, 1953, pp. 186-93. See also C Ortbauer, 'Die medizinische
Geographie des Arztes Leonhard Ludwig Finke (1747-1837)', unpublished doctoral thesis, University of Freiburg im Breisgau, 1993.

${ }^{2}$ F Sargent II, Hippocratic heritage: $a$ history of ideas about weather and human health, New York, Oxford, Toronto, Sydney, Paris, Frankfurt, Pergamon Press, 1982, pp. 269-78.

${ }^{3}$ A Hirsch, Handbook of geographical and historical pathology, 3 vols, London, New Sydenham Society, 1883-6. 


\section{Nicolaas Rupke}

geographers were plotted. ${ }^{4}$ This simple Finke-to-Hirsch story has been told also in the subsequent secondary literature; today it remains fundamentally unchanged. ${ }^{5}$

\section{Definition of Humboldtian Medicine}

A close look at the primary literature shows, however, that medical geography was not a single current, but developed into several different, anastomosing streams. In Britain, for example, there predominated a kind of medical geography that was focused on tropical environments, with the utilitarian aim of helping British soldiers and other Europeans cope with unfamiliar climatic conditions in overseas colonial possessions; aetiology, although not ignored, was of secondary concern, and medical practice came first. Examples range from James Annesley's Researches into the causes, nature and treatment of the more prevalent diseases of India (2 vols, 1828; 2nd and 3rd abridged editions, 1841, 1855), which concluded with a chapter 'On the management of European troops upon arrival in India', to the six times reprinted Influence of tropical climates on European constitutions, written by James Johnson and James Ranald Martin (1st edition 1841; 1856 edition by Martin only). The 1832 'Sketch of the geographical distribution of diseases', regularly cited by contemporary authors and written by the deputy inspector-general of army hospitals Henry Marshall, belonged to this genre of practical tropical medicine: "It is not my intention in this paper to account for the causes of diseases", Martin wrote. ${ }^{6} \mathrm{~A}$ German example of medical geography written from a practical point of view was Moritz Hasper's Ueber die Natur und Behandlung der Krankheiten der Tropenländer (2 vols, 1831), published for the benefit of doctors and travellers to the tropics.

At the time, the German lands did not belong to the club of European colonial powers, and Hasper's practice-orientated Krankheiten der Tropenländer was something of an exception in the German-speaking world. Here, apart from the cited books by Finke and Hirsch, a modest body of literature on medical geography developed that I propose to call "Humboldtian medicine". This was a form of medical geography that made the then new science of physical geography - synonymous with Alexander von Humboldt's name-its basis, taking from it a scientific model of both explanation and representation for the

\footnotetext{
${ }^{4}$ A Hirsch, Geschichte der medizinischen Wissenschaften in Deutschland, photomechanical reproduction of the 1893 edition, New York, Johnson Reprint Corporation, and Hildesheim, G Olms Verlagsbuchhandlung, 1966, pp. 368-9, 703-4.

5 See for example A Barkhuus, 'Medical geographies', Ciba Symposia, 1945, 6: 1997-2016; E A Ackerknecht, Geschichte und Geographie der wichtigsten Krankheiten, Stuttgart, F Enke, 1963, p. 3; C Hannaway, 'Environment and miasmata', in W F Bynum and R Porter (eds), Companion encyclopedia of the history of medicine, vol. 1, London and New York, Routledge, 1993, pp. 301-2. Other secondary sources on the history of medical geography are: F A Barrett, 'Medical geography as a foster child', in M S Meade (ed.), Conceptual and methodological issues in medical geography, Chapel Hill, University of North Carolina, 1980; and idem, 'Medical geography', in M Pacione (ed.), Medical
}

geography, London, Croom Helm, 1986. Barrett deserves credit for having drawn attention, not only to Finke and Hirsch, but also to Schnurrer, Fuchs and Mühry. The connection of medical geography with medical topography is discussed by $\mathrm{H} \mathrm{J} \mathrm{Jusatz,} \mathrm{'Die}$ Bedeutung der medizinischen Ortsbeschreibungen des 19. Jahrhunderts für die Entwicklung der Hygiene', in W Artelt and W Rüegg (eds), Studien zur Medizingeschichte des 19. Jahrhunderts. Band I: Der Arzt und der Kranke in der Gesellschaft des 19. Jahrhunderts, Stuttgart, F Enke, 1967, pp. 179-200.

${ }^{6} \mathrm{H}$ Marshall, 'Sketch of the geographical distribution of diseases', Edin. med. surg. J., 1832, 38: $330-52$, p. 331 . For a list of 100 nineteenthcentury publications on medical geography and tropical hygiene, see Verzeichnis der Büchersammlung der Kaiser Wilhelms-Akademie für das Militärärztliche Bildungswesen, 3rd edn, Berlin, Verlag A Hirschwald, 1906, pp. 97-100. 


\section{Humboldtian Medicine}

global variations of health and diseases. Neither the tropical medical geographers did this nor, for that matter, did Finke or Hirsch: they were interested in environmental factors, but not in the science of geography, even though Finke used the criterion of latitude for dividing the subject matter of his Versuch into chapters. He conceived of the idea for his book in 1780, and wrote long before Humboldt, Carl Ritter and other founders of modern geography had made an impact; his basic intent was to write a medical history of mankind. Hirsch grew up during the glory days of German geography, yet he explicitly rejected the application of this branch of modern science to the study of the global distribution of diseases (see below), nor did he make use of cartographic representation. The Humboldtian medics, by contrast, had physical geography written in their banner, grafting their medical interests on the scientific systems of climatology, meteorology, geology, biogeography and, to a lesser extent, anthropology and ethnography. Humboldt was the most celebrated of their scientific leaders, but they were indebted also to others, such as the geologist Leopold von Buch, the geographer Heinrich Berghaus, the botanist/geographer Joakim Schouw, and the physicists/meteorologists Ludwig Friedrich Kämtz and Heinrich Wilhelm Dove. ${ }^{7}$

The here proposed definition of "Humboldtian medicine" should not be confused with Humboldt's contributions to experimental physiology. The theme "Humboldt and medicine", addressed in recent years by several historians, has primarily concerned Humboldt's early contributions to Galvanic phenomena, which were published in his twovolume Versuche über die gereizte Muskel- und Nervenfaser (1797). ${ }^{8}$ Other interests of Humboldt that have been discussed under the heading "medicine" include his technical inventions to help miners operate underground in poisonous air. ${ }^{9}$ Humboldt's views on the cause of infectious diseases such as malaria and yellow fever, however, do have a connection with medical geography (see below). ${ }^{10}$

The most significant of the few outspoken representatives of Humboldtian medicine was (Adalbert) Adolph Mühry (1811-88), a member of a well-known medical family, whose father, Georg Friedrich Mühry, himself a son and cousin of physicians and surgeons, was physician in ordinary ("Leibarzt") to the Hanoverian King, and whose brother, Karl Mühry, was court physician ("Hofmedicus") in Hanover. Adolph, too, made his career in Hanover, becoming member of the royal medical board ("königlicher Sanitätsrath"). All three were medical alumni of the University of Göttingen, and in 1854 Adolph settled as "Privatgelehrter" in this town where in 1833 he had obtained his MD. Here he wrote a trilogy on medical geography, first the Grundzüge der Noso-Geographie (1856), followed by the Grundzüge der Klimatologie (1858), and last Allgemeine

\footnotetext{
${ }^{7}$ See for example A Mühry, Allgemeine geographische Meteorologie, note 11 below, p. vi; and C F Fuchs, 'Über die Aufgaben und die Wichtigkeit der medizinischen Geographie', Archiv des Vereins für gemeinschaftliche Arbeiten zur Förderung der wissenschaftlichen Heilkunde, 1853-4, 1: 253, 256.

${ }^{8}$ See for example W F Kümmel, 'Alexander von Humboldt und die Medizin', in W-H Hein (ed.), Alexander von Humboldt: Leben und Werk, Frankfurt am Main, Weisbecker, 1985.
}

\footnotetext{
${ }^{9}$ Ibid.; see also E H Berninger, 'Humboldts technische Erfindungen und Neuerungen für den Bergbau', in M Guntau, P Hardetert and M Pape (eds), Alejandro de Humboldt: La naturaleza, idea y aventura, Essen, Projekt Agentur, 1993.

10 V Löwenthal, 'Alexander von Humboldt's Ansichten über Infektionskrankheiten', Janus, 1910, 15: 282-93.
} 


\section{Nicolaas Rupke}

geographische Meteorologie (1860). In addition, Mühry produced several books and a large number of papers on climatology and meteorology. ${ }^{11}$

An early representative of Humboldtian medicine was Friedrich Schnurrer (1784-1833), who, having obtained his doctorate in 1805 from the University of Tübingen, where his father, Christoph Friedrich, was professor of oriental languages and a one-time chancellor, worked for much of his career as physician in Vaihingen a.d. Enz, a town near Stuttgart. His contribution to medical geography appeared under the title Geographische Nosologie (1813). He wrote various other books, mainly on epidemiology and contagious diseases, and made a name for himself with a study of the history of epidemics, Chronik der Seuchen (2 vols, 1823-25). ${ }^{12}$

A third, and the least prominent of the three Humboldtians here discussed, was Caspar Friedrich Fuchs (1803-66), physician in Brotterode, a town in Thüringen. He, too, was much interested in epidemiology, but also in medical topography. His Medizinische Geographie appeared in $1853 .^{13}$

\section{Characteristics}

Susan Cannon, in her seminal paper on 'Humboldtian science', defined this concept as the activities of many scientists in the early part of the nineteenth century that were inspired by Humboldt's comprehensive approach to astronomy, physics of the earth, and biology, especially biogeography, "all viewed from a geographical standpoint, with the goal of discovering quantitative mathematical connections and interrelationships'laws', if you prefer, although they may be charts or graphs."14 As characteristics she stressed the use of precision instruments for measuring global variables (coordinates, altitude, temperature, humidity, magnetism, etc.) and an innovative way of plotting these,

\footnotetext{
11 The complete bibliographical data are as follows: A Mühry: Die geographischen Verhältnisse der Krankheiten, oder Grundzüge der NosoGeographie, in ihrer Gesammtheit und Ordnung und mit einer Sammlung der Thatsachen dargelegt, 2 vols, Leipzig and Heidelberg, C F Winter, 1856; Klimatologische Untersuchungen oder Grundzüge der Klimatologie in ihrer Beziehung auf die Gesundheits-Verhältnisse der Bevölkerungen. Mit einer geographisch geordneten, die gesammte Erde umfassenden Sammlung klimatographischer Schilderungen, Leipzig and Heidelberg, C F Winter, 1858; Allgemeine geographische Meteorologie oder Versuch einer übersichtlichen Darlegung des Systems der Erd-Meteoration in ihrer klimatischen Bedeutung, Leipzig and Heidelberg, C F Winter, 1860. Publications by Mühry of related interest, and not cited below, include Über die historische Unwandelbarkeit der Natur und der Krankheiten, Hanover, Verlag der Hahn'schen Hofbuchhandlung, 1844; see also note 52 below.

12 The complete references are F Schnurrer, Geographische Nosologie oder die Lehre von den Veränderungen der Krankheiten in den verschiedenen Gegenden der Erde, in Verbindung mit physischer Geographie und Natur-Geschichte des
}

Menschen, Stuttgart, J F Steinkopf, 1813; Die Krankheiten des Menschen-Geschlechts historisch und geographisch betrachtet. Der historische Abteilung: Chronik der Seuchen in Verbindung mit den gleichzeitigen Vorgängen in der physischen Welt und in der Geschichte der Menschen, Tübingen, C F Osiander, vol. 1, 1823, vol. 2, 1825. Of related interest was Schnurrer's Materialien zu einer allgemeinen Naturlehre der Epidemieen und Contagien, Tübingen, J F Heerbrandt, 1810; see also note 32 below.

13 The complete reference is as follows:

C F Fuchs, Medizinische Geographie, Berlin, Verlag A Duncker, 1853; of related interest was his Die epidemischen Krankheiten in Europa in ihrem Zusammenhange mit den Erscheinungen des Erdmagnetismus, den Vorgänge in der Atmosphäre und der Geschichte der Kulturvölker dieses Erdtheils, Weimar, Voigt, 1860. Fuchs co-authored with a mining inspector a medical topography: C F Danz and C F Fuchs, Physisch-medicinische Topographie des Kreises Schmalkalden, Marburg, N G Elwert, 1848.

${ }^{14}$ S F Cannon, Science in culture: the early Victorian period, New York, Dawson and Science History Publications, 1978, p. 77. 


\section{Humboldtian Medicine}

in particular on iso-maps. Malcolm Nicolson, in a paper that significantly went beyond Cannon's, has emphasized the importance that plant geography occupied in the Humboldtian, holistic approach. ${ }^{15}$ Others, such as Margarita Bowen and Mary Louise Pratt, have drawn attention to Humboldt's strong socio-political engagement and to the fact that human geography was an integral part of his physical world description. ${ }^{16} \mathrm{~A}$ way of defining Humboldtian medicine, other than by stating that it made use of physical geography, is to say that its practitioners expanded the scope of the Humboldtian programme to include a systematic study of the global variable of human diseases, making use of the concepts, terminology and representational forms of the new plant geography.

Let us look more closely at the features that made medical geography Humboldtian. Most upfront, there were attributions to Humboldt. Whereas Finke had dedicated his book "To all anthropologists and true admirers of Hippocrates' book on Air[s], Waters and Places", Mühry dedicated his Grundzüge der Noso-Geographie to Alexander von Humboldt, "The greatest scientist of our century whose observations, interpretations and the totality-embracing overviews have provided the ground rules also for the present work"; and his Grundzüge der Klimatologie was dedicated to one of Britain's most Humboldtian of scientists, Sir John Herschel, "whose national origin in Germany will never be forgotten". The dedication of the Allgemeine geographische Meteorologie, the third of Mühry's trilogy on medical geography, was addressed to "The International Statistical Congress as it has met in the years 1853, 1855 and 1857 in Brussels, Paris and Vienna".

\section{General Laws of Distribution}

Attributions to Humboldt by themselves do not mean that the books to which his name was attached were necessarily Humboldtian in substance, and the question remains: what were their substantive Humboldtian characteristics? First, the main purpose of their authors was to present an integrated picture of the global occurrence of human diseases with the intent of uncovering general laws of distribution. By taking on board physical geography the medical geographers meant to acquire a framework for putting dispersed observations together in a way that would yield general results.

Schnurrer, citing Humboldt's early classics, Ansichten der Natur (1808) and, in German translation (2 vols, 1811), Essai politique sur le royaume de la Nouvelle Espagne, argued that separately observed nosological and pathological phenomena should be put together in a necessary relationship to elucidate their origins and transitions. ${ }^{17}$ Fuchs defined medical geography as "The knowledge of the laws according to which diseases are distributed and spread across the earth". ${ }^{18}$ It was physical geography-he maintainedthat provided the means for extracting these laws from the multiplicity of isolated observations. Mühry, too, looked for a "law-like arrangement of diseases across the entire

\footnotetext{
${ }^{15} \mathrm{M}$ Nicolson, 'Alexander von Humboldt, Humboldtian science and the origins of the study of vegetation', Hist. sci., 1987, 25: 167-94.

${ }_{16} \mathrm{M}$ Bowen, Empiricism and geographical thought: from Francis Bacon to Alexander von Humboldt, Cambridge University Press, 1981, pp. 210 et seq.; M L Pratt, Imperial eyes: travel
}

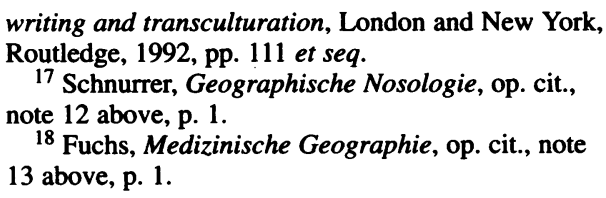

${ }^{18}$ Fuchs, Medizinische Geographie, op. cit., note 13 above, p. 1 . 


\section{Nicolaas Rupke}

known earth". ${ }^{19}$ His purpose was to present not a patchwork quilt of connected medical topographies, but an integrated, single geography for the purpose of finding worldwide trends.

\section{Diseases as Plants}

A second characteristic of Humboldtian geography, which provides an example of the general laws that the Humboldtians were after, is that infectious diseases were conceived of as plants and, like these, were believed to be distributed according to well-defined regions and zones, each type of vegetation/disease having its own characteristic area of distribution. Schnurrer saw in the global spread of plants and animals an analogy to help understand the pattern of occurrence of human diseases; plant geography showed the way to a scientific nosology:

It is impossible to found a science of plants on the flora of a single region, but one must compare types of plants from across the earth; equally, an understanding of diseases is not possible when these are taken in isolation, but they must be considered in their totality, and nosological systems can only be constructed when the most important types of diseases and their causes have been compared. ${ }^{20}$

Schnurrer wrote his book before the Humboldtian programme had reached its full development. Fuchs, by contrast, published when the whole gamut of Humboldtian concepts was available. He, too, argued that the geographical distribution of plants served to indicate how diseases were spread across the globe. Fuchs focused on three groups of diseases, the enteromesenteric, the catarrhal, and the dysenteric. The presence and absence of these diseases-he believed-were a function of physical environment and could therefore be described in terms of climatic zones: the enteromesenteric diseases thrived in northern latitudes and at high altitudes, the catarrhal ones in the middle of the temperate zones, whereas dysenteric diseases predominated in the tropics. ${ }^{21}$ Fuchs believed he had found a similar law of distribution for different types of fevers: the continued, intermitting and remitting fevers.

Mühry, in his early Vergleichung der Medicin in Frankreich, England und Deutschland (1836), had mildly criticized the famous clinician Johann Lucas Schönlein and his school for advocating that diseases are not a condition of the human body but can be described and classified like plant-like organisms. ${ }^{22}$ Yet in his Noso-Geographie, Mühry now also interpreted diseases as a form of plant life. The vegetation of a region was an expression of the physical environment, and so were certain diseases. Plants no longer were studied merely as the flora of a particular place, but as part of a global pattern of vegetation; in the same way, diseases should be scientifically understood as part of integrated geosystems. $^{23}$

\footnotetext{
${ }^{19}$ Mühry, Grundzüge der Noso-Geographie, op. cit., note 11 above, vol. 1 , p. v.

${ }^{20}$ Schnurrer, Geographische Nosologie, op. cit., note 12 above, p. 3.

${ }^{21}$ Fuchs, Medizinische Geographie, op. cit., note 13 above, pp. 7-39.

${ }^{22}$ A Mühry, Darstellungen und Ansichten zur
}

\author{
Vergleichung der Medicin in Frankreich, England \\ und Deutschland. Nach einer Reise in diesen \\ Ländern im Jahre 1835, Hanover, Verlag der \\ Hahn'schen Hofbuchhandlung, 1836, p. 272-8. \\ ${ }^{23}$ Mühry, Grundzüge der Klimatologie, op. cit., \\ note 11 above, p. $x$.
}




\section{Humboldtian Medicine}

Several of the terms with which Mühry described the global spread of diseases were borrowed from contemporary plant geography, e.g., "ubiquitous", "migration", "area", "habitat", and "indigenous". ${ }^{24}$ Using a geographical criterion, he classified diseases into four groups: (1) ubiquitous diseases, which were not temperature-sensitive (smallpox, measles, scarlet fever, whooping cough, and many others) (2) diseases that were temperature-dependent and were enclosed within climatic zones (malaria, yellow fever, cholera, typhoid, etc.), (3) so-called singular-endemic diseases, which occurred in areas with both north-south and east-west borders (e.g., various ulcerations), and-an odd category-(4) diseases that were absent from particular areas (in Ceylon and Hindostan phthisis was rare; in Nubia haemorrhoids did not occur; in North America obesity was so uncommon that people who wanted to loose weight should visit there). For those diseases that were temperature-sensitive, biogeography provided an analogy to describe their distribution, and Mühry concluded that they were most numerous in the tropics, whereas only a few belonged exclusively to the temperate zone of the northern hemisphere, and virtually none to the north polar region or to the temperate zone of the southern hemisphere. $^{25}$

The plant model served Mühry to formulate a new theory of miasmas, which he doúblepublished, in his Noso-Geographie and in the Zeitschrift für rationelle Medicin (1854, 1855). ${ }^{26} \mathrm{He}$ argued that miasmas, which caused such diseases as malaria, yellow fever and cholera, probably were "microscopically small, germinating organisms, most likely fungi and dust-like fungal spores, each with its own toxic properties." 27 Because of their vegetable nature, they were distributed according to temperature and soil. From the independently living miasmic "plants", Mühry distinguished contagia, which, too, were a form of plant-life, "fermentation-fungi"; but they lived parasitically inside the human body, and therefore were independent from temperature and soil, except for a few, namely the contagia that caused plague and typhoid, which, being temperature-sensitive, occurred within climatic zones. ${ }^{28}$

\section{Representational Structures}

A third characteristic of Humboldtian medicine was its use of specific representational forms devised by Humboldt for the purpose of illustrating the global variations of a range of natural phenomena. Having returned from his journey of exploration of the Americas (1799-1804), Humboldt published his Essai sur la géographie des plantes (1805-7) with the 'Tableau physique des Andes et des pays voisins', the iconic cross-sectional profile of the Andes from the Pacific to the Atlantic at the latitude of Chimborazo, showing the zoned occurrence of different plants at different altitudes. ${ }^{29}$ Subsequently, Humboldt

\footnotetext{
${ }^{24}$ Idem, Grundzüge der Noso-Geographie, op. cit., note 11 above, vol. 1 , p. 75.

25 Ibid., pp. 76-121.

26 Ibid., pp. 122-54; Mühry, 'Über die Natur der Miasmen, als vegetabilische Organismen vorgestellt; aus geographischem Gesichtspunkte', Zeitschrift für rationelle Medicin, 1854, n.s. 5: 286-306.

${ }^{27}$ Mühry, Grundzüge der Noso-Geographie, op. cit., note 11 above, p. 123.

${ }^{28}$ Ibid., 156; see also Mühry, 'Über den Unterschied der contagiösen und der miasmatischen
}

Krankheiten, besonders über die Contagien der Pest und des Typhus; vom geographischen Standpunkte', Zeitschrift für rationelle Medicin, 1855 , n.s. 6: 211-26.

29 The German translation was dedicated to Goethe: Ideen zu einer Geographie der Pflanzen, nebst einem Naturgemälde der Tropenländer, auf Beobachtungen und Messungen gegründet, welche vom 10. Grade nördl. bis zum 10. Grade südl. in den Jahren 1799-1803 angestellt worden sind, Tübingen, J G Cotta, 1807. 


\section{Nicolaas Rupke}

added to his Nova genera et species plantarum (vol. 1, 1815) a table, 'Geographiae plantarum lineamenta', that showed the vertical, zoned distribution of plants on three mountains, one in the tropics, another in the temperate region and a third in a polar region -demonstrating his famous "law" that the changes in plant distribution by altitude matched the ones by latitude (Plate 1). ${ }^{30}$ This law was again depicted, by Heinrich Berghaus, in his Physikalischer Atlas (see below), showing side by side vegetation profiles on Tenerife and in the Himalayas. ${ }^{31}$

In the most striking instance of a transfer of representational structures, Fuchs used Humboldt's "lineamenta" (without attribution), approximately locating dysentery in the habitat of palms, enteromesenteric problems in the lower region of deciduous trees, and catarrh in the upper region of deciduous trees and the zone of conifers. The arctic and the snow-covered mountain tops were essentially free of these diseases (Figure 1). To illustrate the latitude/altitude relationships, he devised a graph that showed a pattern of continuous change in the occurrence of his three groups of diseases from pole to equator, and from low to high altitude (Figure 2).

The Humboldtians led the way in plotting distribution patterns of diseases on world maps. Already in 1827, Schnurrer presented a 'World map showing the areas of distribution of diseases' to the Versammlung deutscher Naturforscher und Ärzte, subsequently adding one that showed the worldwide occurrence of cholera for the period August 1817 to October $1830 .^{32}$ Cannon remarks that a Humboldtian can be spotted by his use of isomaps. ${ }^{33}$ Fuchs and, more sophisticatedly, Mühry did indeed employ this Humboldtian representational device. In 1817, Humboldt had proposed to depict the distribution of heat over the northern hemisphere by means of isotherms. ${ }^{34}$ Fuchs now showed the global distribution of temperature-sensitive diseases on an isotherm map, and so did Mühry (Plate 2). The distribution zone of malaria (a miasmic disease) and of typhoid (a contagious disease susceptible to temperature differences) were delineated by specific isotherms: the northern limit of malaria was the $40^{\circ} \mathrm{F}$ isotherm, whereas the southward spread of typhoid went no further than the $74^{\circ} \mathrm{F}$ isotherm.

The pictorial culmination of Humboldtian medicine took place within the geographical literature: it was a map in Heinrich Berghaus' monumental Physikalischer Atlas (1845-48; 2nd edition, 1852; 3rd edition, 1892) - an accompaniment to Humboldt's

\footnotetext{
30. Nova genera et species plantarum, quas in peregrinatione ad plagam aequinoctialem orbis novi collegerunt, descripserunt, partim adumbraverunt Amat. Bonpland et Alex. de Humboldt. Ex schedis autographis Amati Bonplandi in ordinem digessit Carol. Sigismund. Kunth. Accedunt tabulae aeri incisae, et Alexandri de Humboldt notationes ad geographiam plantarum spectantes, vol. 1, Paris, Librairie Grecque-Latine-Allemainde, 1815.

${ }^{31}$ H Berghaus, 'Umrisse der Pflanzengeographie'; this map was printed in Gotha, by J Perthes, in 1838, and published in Berghaus: Physikalischer Atlas, Gotha, J Perthes, 1848, part 5, map 1.

${ }^{32} \mathrm{~F}$ Schnurrer, 'Charte über die geographische Ausbreitung der Krankheiten, vorgelegt der Versammlung der deutschen Ärzte und Naturforscher zu München den 22. September 1827',

Staatsbibliothek zu Berlin, Kartensammlung,
}

SB Kart. W 24290 S; see also idem, 'Weltcharte mit dem Verbreitungsbezirk der Krankheiten', Isis, 1828 , 21: 519; the cholera distribution map was published in idem, Die Cholera morbus, ihre Verbreitung, ihre Zufälle, die versuchte Heilmethoden, ihre Eigenthümlichkeiten und die im Grossen dagegen anzuwendenden Mittel. Mit der Karte ihres Verbreitungsbezirks, Stuttgart and Tübingen, J G Cotta, 1831.

${ }^{33}$ Cannon, op. cit., note 14 above, p. 95.

${ }^{34}$ A von Humboldt, 'Des lignes isothermes et de la distribution de la chaleur sur le globe', Mémoires de physique et de chemie, de la Société d'Arcueil, 1817, 3: 462-602; it was multiply published, appearing for example in the Edin. philos. J., 1820, 3: $1-20,256-74 ; 1821,4$ : 23-38, 262-81; 1821, 5: $28-39$. 


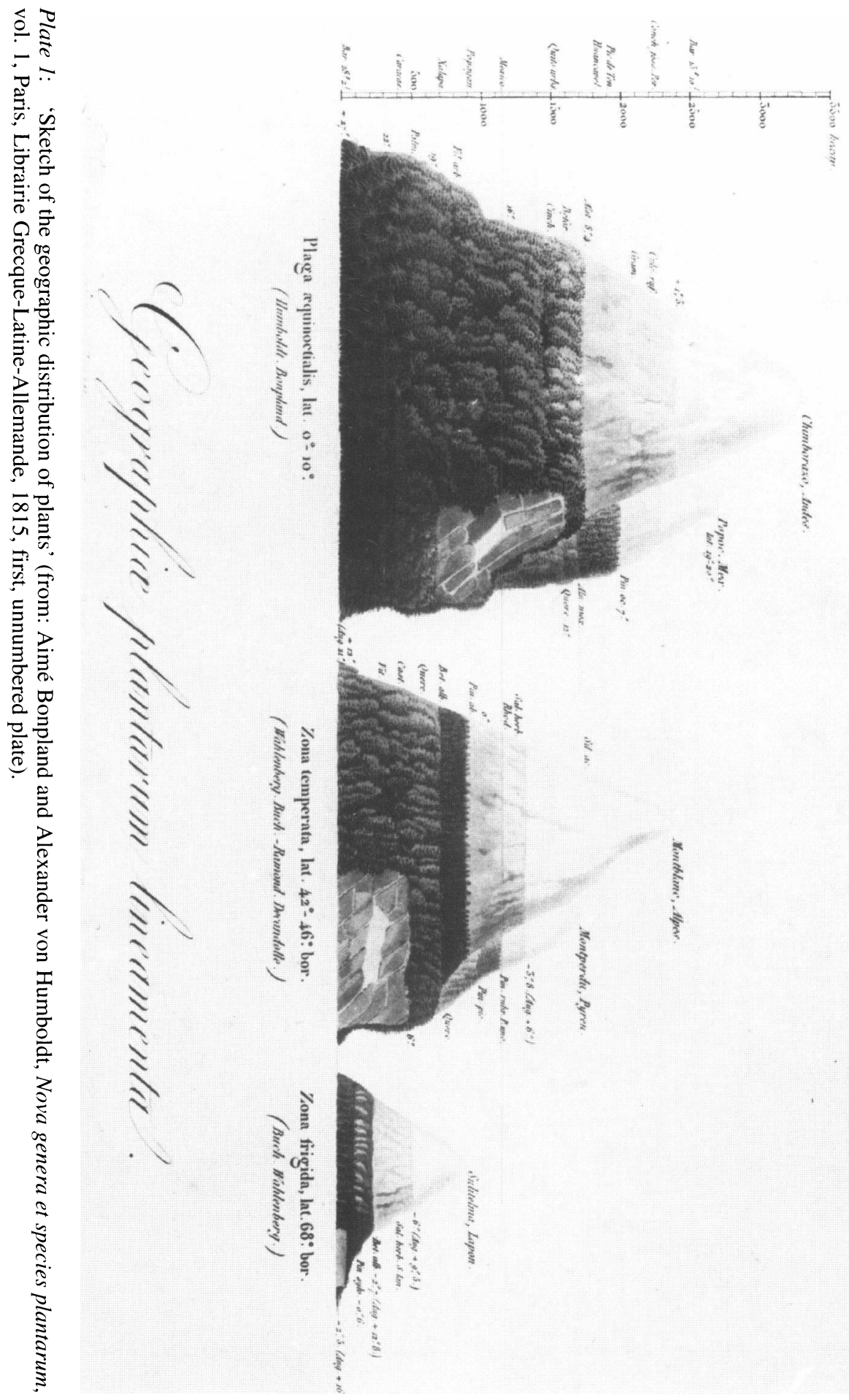




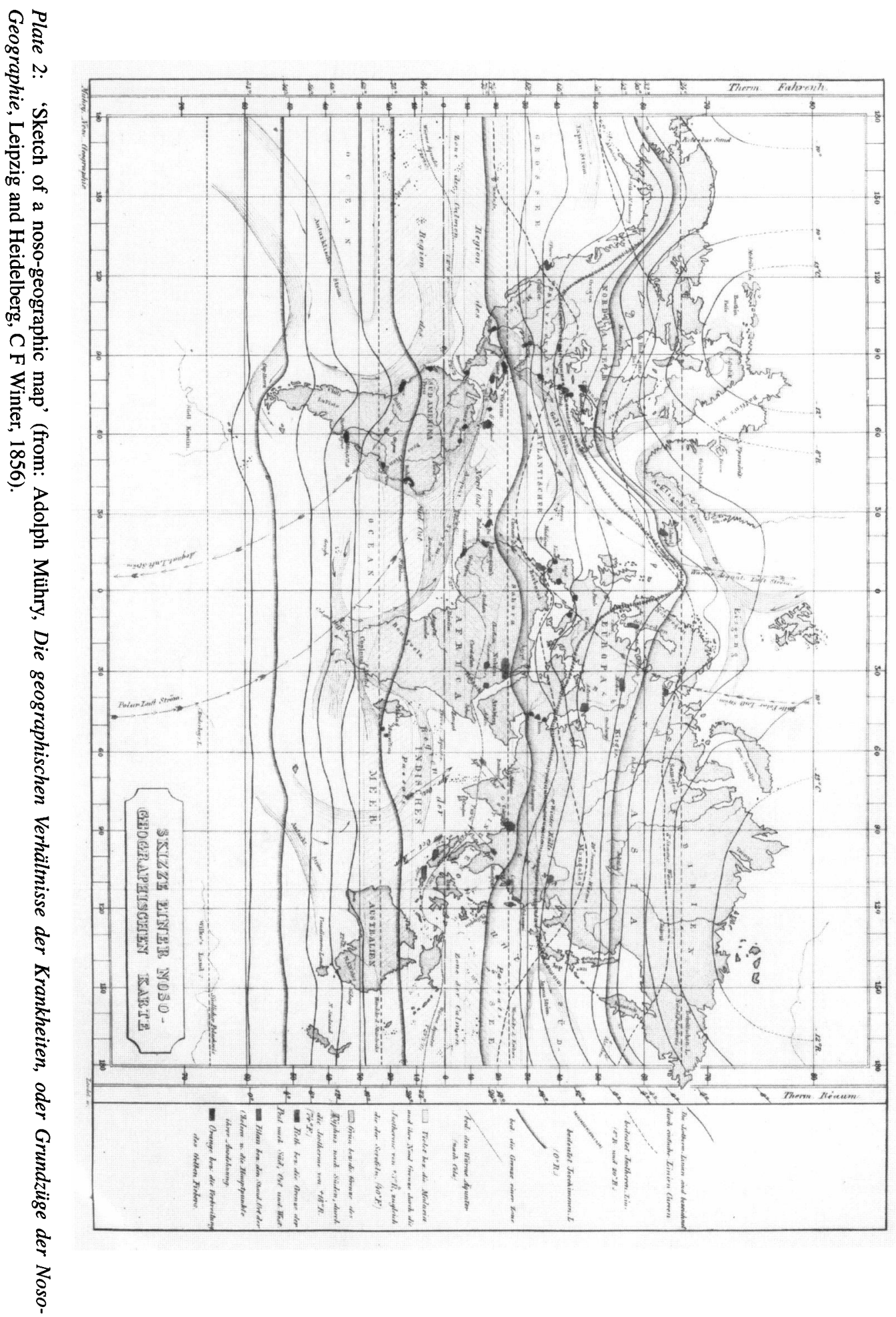




\section{Humboldtian Medicine}

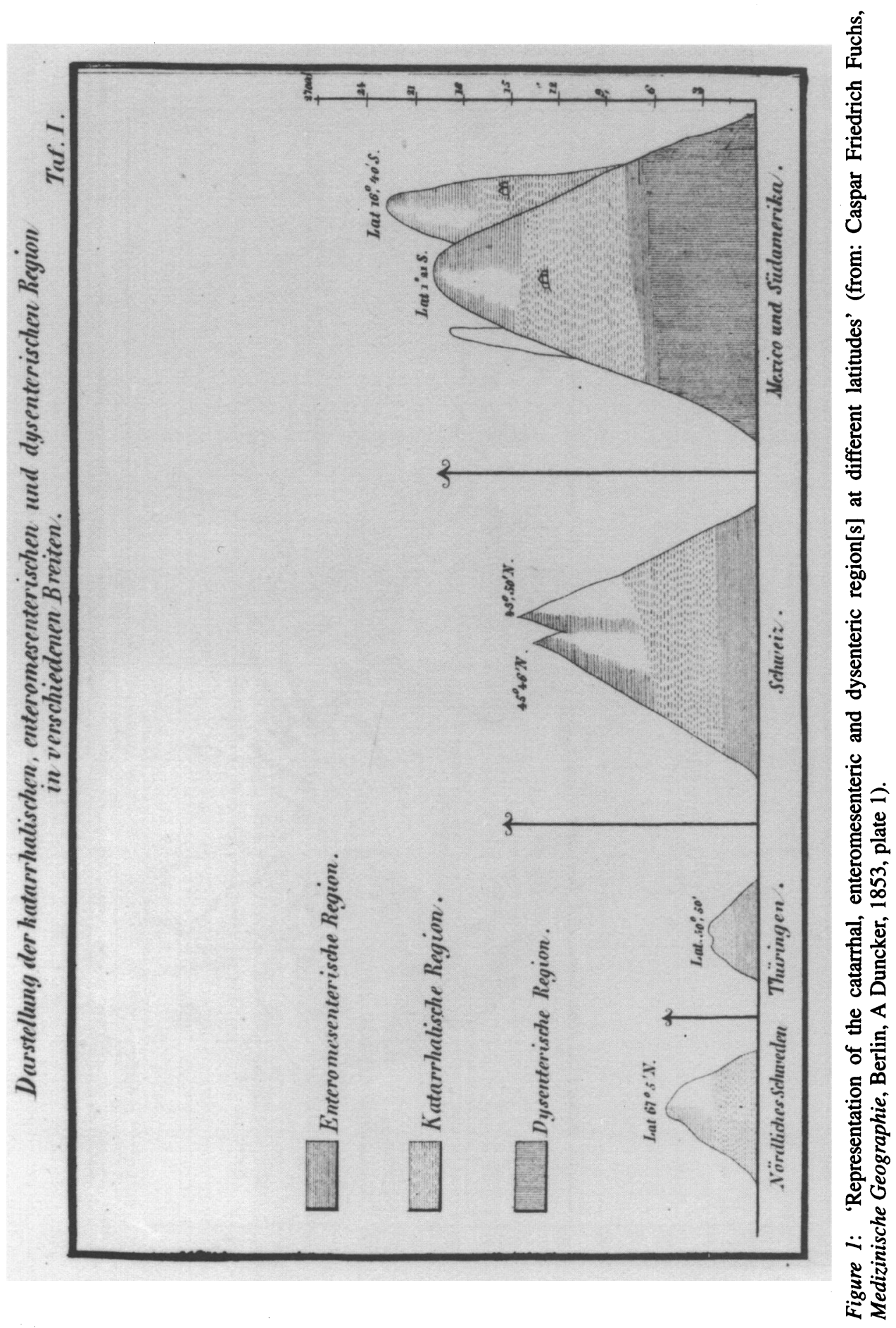




\section{Nicolaas Rupke}

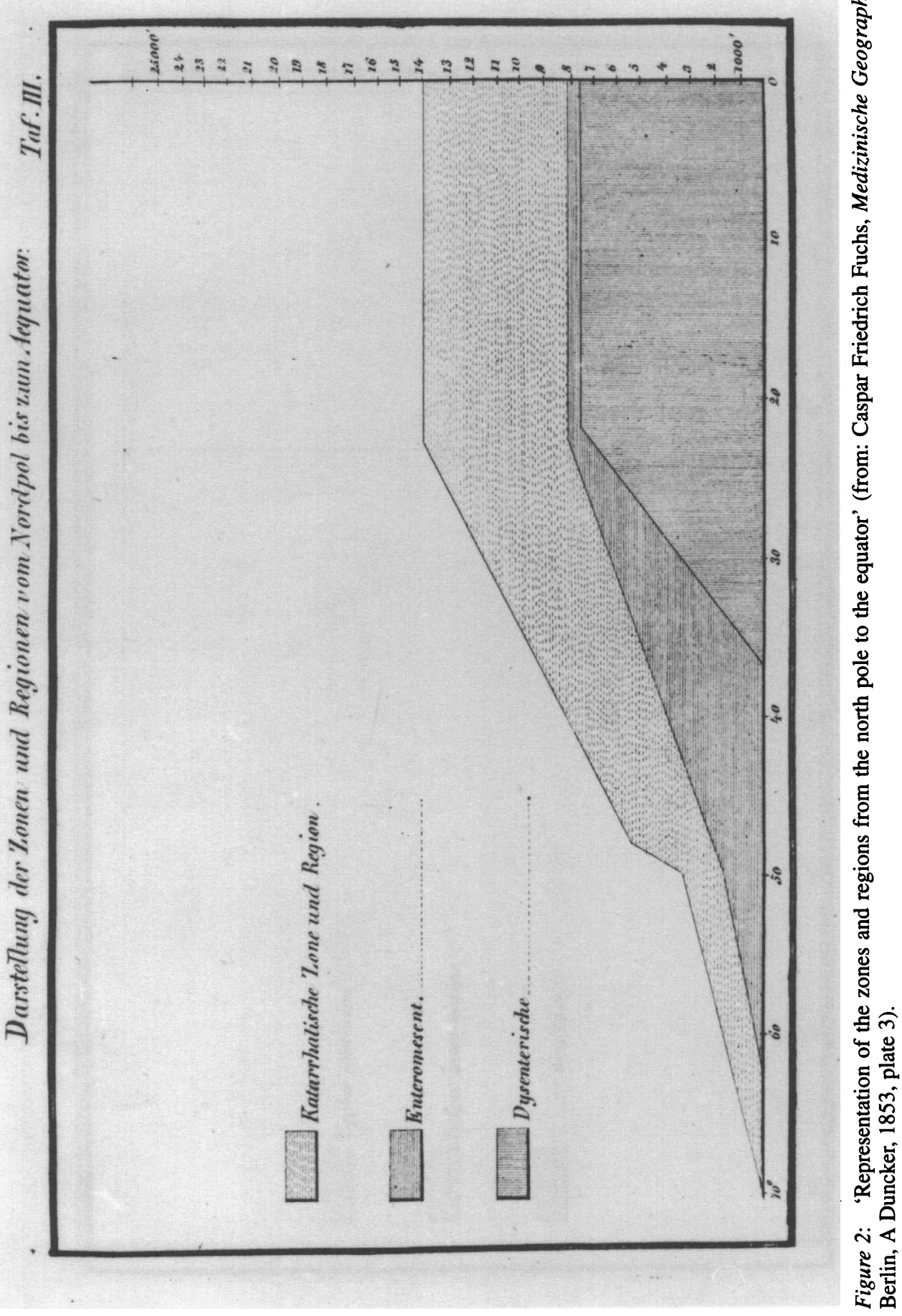




\section{Humboldtian Medicine}

Kosmos - which atlas contained a wide range of novel world distribution maps. An edited version of the atlas for an English-speaking readership was produced by the Edinburgh geographer in ordinary to the queen, Alexander Keith Johnston, entitled The physical atlas of natural phenomena (1848; 2nd edition, 1856). In Germany itself Berghaus was imitated (in part plagiarized) by Traugott Bromme, who without Humboldt's authorization called his volume Atlas zu Alexander von Humboldt's Kosmos (1851). ${ }^{35}$ The map in question was a famous isotherm planiglobe, depicting the geographical distribution of diseases: 'Planiglob zur Übersicht der geographischen Verbreitung der vornehmsten Krankheiten, denen der Mensch auf der ganzen Erde ausgesetzt ist' ${ }^{36}$ It incorporated the work done by Schnurrer and Mühry. Johnston was much praised for his particular version (which did not appear in the first edition of his atlas), both by Mühry ${ }^{37}$ and by the British and Foreign Medico-Chirurgical Review, which published a joint review of Mühry's Noso-Geographie and Johnston's map. ${ }^{38}$

To help produce Johnston's Physical atlas, two of Berghaus' cartographic pupils, Henry Lange and August Petermann, travelled to Edinburgh. The latter stayed there from 1845 to 1847 and subsequently moved to London where he lived until 1854 . Here Petermann founded his own cartographic establishment and worked on British maps. Among his pioneering contributions to medical cartography was a cholera map of the British Isles (1852), showing areas affected during the epidemic of 1831-33. ${ }^{39}$

The medical world map by Berghaus and Johnston, by being presented together with other maps, showing the global occurrence of different religions, types of government, culture ("geistige Bildung") etc., fed into the Eurocentric triumphalism of the time. "Geistige Bildung", for example, was shown as at a maximum in Christian, Protestant, northwestern Europe. ${ }^{40}$ Fuchs subscribed to these Euro-glorification views, joining to his disease distribution maps various other charts - unacknowledged, simplified copies of Berghaus' maps - concerned with human races, diet, dress, and domesticated plants. The people in the enteromesenteric zone, dominantly Caucasians, were the most beautifully proportioned, with the highest mental development, possessing true virtue and courage etc. ${ }^{41}$ Mühry was more restrained, hinting merely at the superior salubrity of "our temperate, northern-hemispherical zone, in comparison with the tropics", but in addition he pointed out that the southern temperate zone, most particularly New Zealand, had a higher degree of salubrity yet, as had the polar regions. ${ }^{42}$

\footnotetext{
${ }^{35}$ For a discussion of the atlases, see Hanno Beck (ed.), Alexander von Humboldt. Kosmos, Darmstadt, Wissenschaftliche Buchgesellschaft, 1993, vol. 2, pp. 363-87.

${ }^{36} \mathrm{H}$ Berghaus, 'Planiglob zur Übersicht der geographischen Verbreitung der vornehmsten Krankheiten, denen der Mensch auf der ganzen Erde ausgesetzt ist', Physikalischer Atlas, 2nd edn, Gotha, J Perthes, 1852, vol. 2, part 7, plate 2. A K Johnston, 'The geographical distribution of health and disease', Physical atlas of natural phenomena, 2nd edn, Edinburgh and London, W Blackwood, 1856, p. 117, plate 35 .

${ }^{37}$ Mühry, Grundzüge der Klimatologie, op. cit., note 11 above, p. xii.
}

\footnotetext{
38 Anon., 'The geography of disease', British and Foreign Medico-Chirurgical Review or Quarterly Journal of Practical Medicine and Surgery, 1857, 19: 312-22.

${ }^{39}$ See E W Gilbert, 'Pioneer maps of health and disease in England', Geog. J., 1958, 124: 172-83.

40 Berghaus, 'Verschiedenes zur Anthropographie', in Physikalischer Atlas, op. cit., note 36 above, plate 4.

${ }^{41}$ Fuchs, Medizinische Geographie, op. cit., note 13 above, pp. 129-40, plates 8-11.

${ }^{42}$ Mühry, Grundzüge der Noso-Geographie, op. cit., note 11 above, vol. 1 , p. 108.
} 


\section{Nicolaas Rupke}

Such Eurocentricity-it should be added-was not an exclusively Humboldtian feature in medical geography, but characterized much of the subject in general. F Bisset Hawkins, for example, in his Gulstonian Lectures delivered at the Royal College of Physicians on Elements of medical statistics (1829), while stating the non-Humboldtian belief that "the maladies of the individual appear to depend much more upon his habits and condition, and occasional local peculiarities, than upon the varieties of climate", also expressed a conviction in the medical superiority of his own climate:

The temperate zone is the most favourable to health, but as its extremities approach the frigid and the torrid zones, they partake of the dispositions peculiar to these; and in proportion as they border more nearly on either, are more subject to the morbific influence arising from vicissitudes of seasons and of weather. Between the 40th and 60th degree the succession of the four seasons is the most regular and the most sensible, without, however, exposing the health of man. It is between these latitudes that the most civilised and prosperous nations are found: the natural term of life is here more generally attained; diseases are less virulent, less rapid in their progress, less unsightly, less fatal. ${ }^{43}$

\section{Discussion}

\section{Relative Lack of Success}

Even though therapeutic benefits were not a primary concern to the Humboldtians, they did discuss these. Once the natural regions of climate-sensitive diseases are established, a cure can be effected by moving patients to latitudes or altitudes that are outside a particular range of occurrence. Phthisis, for example, could be cured by a transfer of affected people to "exempted areas", at high latitudes and altitudes, but also to northern Africa (Algeria, Egypt) or the East Indies (including Ceylon, mentioned above). ${ }^{44}$ Fuchs commented: "for just as plants from lowland areas very rapidly wilt and die on the mountains, so do lowland diseases wilt there, whereas patients from mountainous regions feel well in warm lowland areas."45

Sending sick people to health resorts was by no means a uniquely Humboldtian practice: in the German-speaking world, Joseph Pircher recommended Meran, in Tyrol, for its beneficial environment; Karl Ludwig Sigmund prescribed spas on the Adriatic and Mediterranean; whereas Wilhelm Reil-Bey promoted Egypt as a winter resort for patients. ${ }^{46}$ In both Britain and France, too, there existed an extensive literature on the subject, examples of which are James Clark's The sanative influence of climate (1829; 3rd edition, 1841) and Les Climats des montagnes considérés au point de vue médical (1856;

\footnotetext{
${ }^{43}$ F B Hawkins, Elements of medical statistics; containing the substance of the Gulstonian Lectures delivered at the Royal College of Physicians: with numerous additions, illustrative of the comparative salubrity, longevity, mortality, and prevalence of diseases in the principal countries and cities of the civilized world, London, Longman, Rees, Orme, Brown, and Green, 1829, p. 194.

${ }^{44}$ Mühry, Grundzüge der Klimatologie, op. cit., note 11 above, pp. 73-98.

${ }^{45}$ Fuchs, Medizinische Geographie, op. cit., note 13 above, p. viii.
}

\footnotetext{
$46 \mathrm{~J}$ Pircher, Meran, als klimatischer Curort,.mit Rücksicht auf dessen Molken- und TraubencurAnstalt, Vienna, Braumüller, 1860; K L Sigmund, Südliche klimatische Curorte, mit besonderer Rücksicht auf Venedig, Nizza, Pisa, Meran und Triest, Vienna, Braumüller, 1857; W Reil-Bey, Aegypten als Winteraufenthalt für Kranke. Zugleich ein Führer für Cairo und Umgegend, Braunschweig, G Westermann, 1859.
} 


\section{Humboldtian Medicine}

3rd edition, 1873), by the Genevan physician Henri-Clermond Lombard. Adolph Mühry's brother Karl was an expert on seaside health resorts, and one of Adolph's early publications was his edition of Karl's posthumous Medicinische Fragmente (1841), which included "a general theory of sea bathing and seaside resorts". 47

However, as pointed out above, the main thrust of Humboldtian medicine was not utilitarian, but scientific-theoretical. The Humboldtians can be seen as participants in the nineteenth-century movement of medical reform, and more particularly in that part of the movement concerned with the development of a scientific medicine. Like comparative anatomy, medical geography was for the "educated physician", irrespective of any practical utility. ${ }^{48}$ The title of Schnurrer's Allgemeine Krankheits-Lehre gegründet auf die Erfahrung und auf die Fortschritte des neunzehten Jahrhunderts (1831) had the ring of reform rhetoric, and in the text Schnurrer declared that geography had served him to provide a scientific foundation for pathology. ${ }^{49}$ Fuchs drew attention to the importance of medical geography in a journal that championed the cause of scientific medicine. ${ }^{50}$ Mühry expressed his commitment to medical reform two decades before he wrote his NosoGeographie, in his interesting 1836 comparison of French, English and German medicine: German medicine-he maintained-had liberated itself from the domination of philosophy and was moving closer to the natural sciences, following the road of empirical learning, to the particular benefit of anatomy, physiology and pathology. ${ }^{51}$ To Mühry, noso-geography was a successful example of scientific medicine. He studied climatology and meteorology, wrote extensively on these subjects, and also designed an improved atmometer (a device to measure the rate of evaporation in the atmosphere). ${ }^{52}$

Yet Humboldtian medicine never became widely established, in contrast to such other forms of scientific medicine as experimental physiology. The subject did not develop much beyond the verge of take-off. In each successive major treatise the potential of the geographic approach was extolled, but at the same time the complaint was made that "Medical geography has not by a long way been given the attention and study it deserves." 53 Mühry's Noso-Geographie began with a quotation from Robert Graves' Clinical lectures of 1848, stating that the geography of diseases had till then remained uncultivated; ${ }^{54}$ and the British and Foreign Medico-Chirurgical Review, in an essay on Mühry's book, pronounced that "[ $t]$ his promising field of research [was] yet in its infancy". ${ }^{55}$ Humboldtian medicine was never more than a genre of medico-geographical

\footnotetext{
${ }^{47}$ K M (also, C) Mühry, Medicinische Fragmente, betreffend: eine allgemeine Lehre des Seebadens und der Seebäder und die Identitätsfrage der Kuhpocken und Menschenpocken, Hanover, Hahn, 1841.

48 Schnurrer, Geographische Nosologie, op. cit., note 12 above, p. iv.

${ }^{49}$ F Schnurrer, Allgemeine Krankheits-Lehre gegründet auf die Erfahrung und auf die Fortschritte des neunzehnten Jahrhunderts, Tübingen, C F Osiander, 1831, pp. iv-v.

${ }^{50}$ Fuchs, op. cit., note 7 above, p. 249.

${ }^{51}$ Mühry, op. cit., note 22 above, p. 270.

52 A Mühry, 'Über ein einfaches, schärfer messendes Atmometer', Annalen der Physik und Chemie, 1861, 113 (4th ser., 23): 305-8; see also idem, Klimatographische Übersicht der Erde,
}

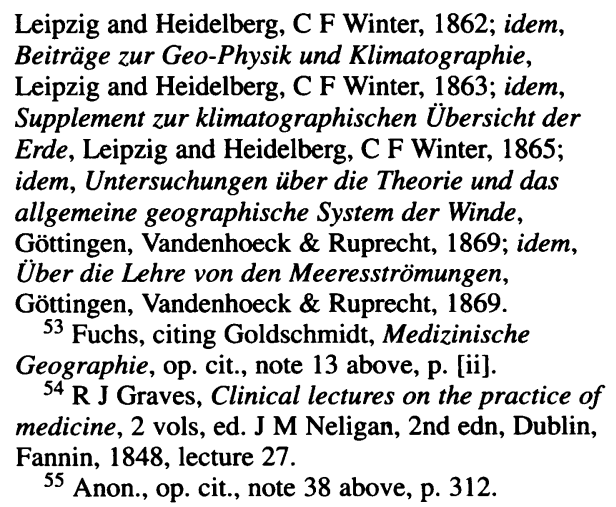

${ }_{55}$ Anon., op. cit., note 38 above, p. 312. 


\section{Nicolaas Rupke}

literature that fed on an admittedly large reservoir of detailed and specialized source reports; although no journals were exclusively devoted to medical geography, for the period 1844-50 the Jahresberichte über die Fortschritte der Medicin contained major sections on "the accomplishments in medical geography", each section consisting of some two hundred publications, listed and discussed by the Marburg professor of medicine Karl Friedrich Heusinger. ${ }^{56}$ The entire second volume of Mühry's Grundzüge der NosoGeographie was devoted to more than 350 references, and in his Grundzüge der Klimatologie he cited over 570.57

In the concluding section of his 1856 book, Mühry proposed the founding of "societies for epidemiology and noso-geography". ${ }^{58}$ The subject never acquired an organized, institutional power base, however, even though the Verein für gemeinschaftliche Arbeiten zur Förderung der wissenschaftlichen Heilkunde, founded in 1852, had as one of its principal aims the promotion of medical geography. ${ }^{59}$ When later the Parisian physician Edouard Carrière published his programmatic Fondements et organisation de la climatologie médicale (1869), he reiterated the proposal to establish a central society for medical climatology, and he accorded the right of priority for founding such an organization to Germany, because of Humboldt, Berghaus and Mühry. ${ }^{60}$ Yet there is no evidence that even lecture courses in medical geography were offered at German universities-Hans-Heinz Eulner cites none; much less were chairs in the subject founded. ${ }^{61}$

The point could be made that the success of Humboldtian medicine was greater than here indicated. There were several French-speaking medical geographers, whose approach showed a certain similarity with that of the Humboldtians. These authors, such as the Frenchman J Ch M Boudin and the above-mentioned Swiss H-C Lombard, were not directly influenced by Humboldt, however, other than that they had read his Kosmos as one of several works on the physical environment. ${ }^{62}$ They did not use the concepts and representational structures of Humboldt's plant geography to describe diseases; nor did they plot their medical data on isotherm maps. Yet they did make extensive use of the results of physical geography, and, more than the Humboldtians, were interested in numbers, publishing lengthy and detailed statistics, both of the physical environment and of morbidity and mortality: "it is to numbers that we have given primary importance" ("c'est au chiffre que nous avons donné une importance primordiale")-Lombard

\footnotetext{
$56 \mathrm{C}$ F Heusinger, 'Bericht über die Leistungen in der medicinischen Geographie', Jahresbericht über die Fortschritte der gesammten Medicin in allen Ländern, 1844 (2): 205-363; 1845 (2): 219-363; 1846 (2): 103-96; 1847 (2): 80-196; 1848 (2): 136-369; 1849 (2): 132-306; 1850 (2): 159-303.

${ }^{57}$ Mühry, Grundzüge der Noso-Geographie, vol. 2, p. iii; Grundzüge der Klimatologie, p. ix, both op. cit., note 11 above.

${ }_{58}$ Idem, Grundzüge der Noso-Geographie, op. cit., note 11 above, vol. 2, p. 280.

59 See note added to Fuchs' paper, op. cit., note 7 above, p. 266, by the editors of the journal, J Vogel, $\mathrm{H}$ Nasse and $\mathrm{F}$ W Beneke.

${ }^{60} \mathrm{E}$ Carrière, Fondements et organisation de la climatologie médicale, Paris, J.-B. Baillière, 1869, p. 77.
}

\author{
${ }^{61}$ H-H Eulner, Die Entwicklung der medizinischen \\ Spezialfächer an den Universitäten des deutschen \\ Sprachgebietes, Stuttgart, F Enke, 1970. \\ $62 \mathrm{~J} \mathrm{C} \mathrm{M} \mathrm{Boudin} \mathrm{wrote} \mathrm{several} \mathrm{books} \mathrm{on} \mathrm{medical}$ \\ geography, of which the most important was his \\ Traité de géographie et de statistique médicales et \\ des maladies endémiques, 2 vols, Paris, J-B Baillière, \\ 1857. H-C Lombard's main treatise on the subject \\ was his Traité de climatologie médicale comprenant \\ la météorologie médicale et l'étude des influences \\ physiologiques pathologiques, prophylactiques et \\ thérapeutiques du climat, 4 vols, Paris, J-B Baillière, \\ vols 1, 2, 1877; vol. 3, 1879; vol. 4, 1880. The \\ treatise was accompanied by an Atlas de la \\ distribution géographique des maladies dans leurs \\ rapports avec les climats, Paris, J-B Baillière, 1880.
}




\section{Humboldtian Medicine}

declared. ${ }^{63}$ Moreover, they were interested in visual representation; Lombard's Atlas de la distribution géographique des maladies dans leur rapports avec les climats (1880) was a classic of its kind. French-language medical geography may in fact represent yet another, different stream of nineteenth-century medical geography, worth further study in the light of what Caroline Hannaway has shown, namely that in the eighteenth century the Royal Society of Medicine of Paris had already organized an extensive network of observers in every province of France whose task it was to record both weather conditions and diseases. $^{64}$

\section{Focus on Physical rather than Social Environment}

Why did Humboldtian medicine suffer this relative lack of success? One could speculate that part of the interest in the subject was siphoned off by such auxiliary subjects as epidemiology, medical statistics, hygiene or indeed colonial medicine. Schnurrer, for one, is better remembered for his epidemiological studies than for his medical geography. I propose, however, that the main reason for the relative lack of success of the Humboldtians was something different, namely that although their endeavours were part of the medical reform movement, they existed merely at its periphery. By the time that Humboldt's Kosmos was published (1845-62), the holistic approach and search for general laws was no longer part of the cutting edge of contemporary science. It may still have reeked of the by then discredited approach of German Naturphilosophie, even though Mühry had explicitly distanced himself from Schelling and the other nature philosophers of the Romantic period. ${ }^{65}$

"Scientific medicine" meant primarily experimental physiology and pathology, practised in the laboratory and flourishing under the institutional control of a new, medical élite. As W F Bynum concludes in his Science and the practice of medicine in the nineteenth century, during the mid- to late-nineteenth-century the "still small but highly visible cadre of individuals who spent most or all of their professional time in medical research, and in teaching the fruits of research", developed into a third estate within medicine, besides the two estates of élite hospital consultants and their more numerous colleagues who practised mostly outside the hospitals. ${ }^{66}$ The leading Humboldtians belonged to the latter estate, and their location outside the centres of university/hospital research meant that they did not have a high profile in the world of German medicine.

A more important factor in the Humboldtian approach's failing to be swept along by the mainstream of the medical reform movement may have been its aetiological tilt, which was decidedly towards physical- rather than social-environmental causes. The movement

\footnotetext{
${ }^{63}$ Lombard, op. cit., note 62 above, vol. 1, p. xvii.

64 C Hannaway, 'The Société Royale de Médicine and epidemics in the Ancien Régime', Bull. Hist. Med., 1972, 46: 267-8. See also L J Jordanova, 'Earth science and environmental medicine: the synthesis of the late Enlightenment', in L J Jordanova and R S Porter (eds), Images of the Earth: essays in the history of the environmental sciences, Chalfont St Giles, British Society for the History of Science, 1979; and Jean-Pierre Peter, 'Malades et maladies à la fin du XVIII' siècle', Annales,
}

économie, société, civilisation, July-Aug. 1967: 711-51.

${ }^{65}$ Mühry, op. cit., note 22 above, pp. 263-9. Mühry repeated his criticism of Naturphilosophie in his teleology-espousing, anti-materialistic treatise Über die exacte Natur-Philosophie, Göttingen, E A Huth, 1877, p. 7.

$66 \mathrm{~W}$ F Bynum, Science and the practice of medicine in the nineteenth century, Cambridge University Press, 1994, pp. 218-19. 


\section{Nicolaas Rupke}

for medical reform in early-nineteenth-century Germany came to a climax during - and as part of-the Revolution of 1848. Kurt Finkenrath, Erwin H Ackerknecht and Johanna Bleker have shown how medical reform was an integral part of the political, revolutionary developments of 1848-49. ${ }^{67}$ The reform movement, whose most prominent representative was Rudolf Virchow, was two-pronged: an improvement was demanded not only in the organization of the medical profession, but also in that of public health. With respect to the first prong, reformers advocated the integration of disparate groups of medical practitioners, the integration also of medical education between the different German states, and the development of a scientific medicine based on materialistic principles. To Virchow, medical reform was, above all - and this concerns the second prong-a matter of revolutionary politics. The medical profession had to be concerned with not just medical questions in the narrow sense of the word, but also social and thus political conditions. Characteristic is the following sentence from the opening article of the radical weekly he edited from 10 July 1848 till 29 June 1849, Die medicinische Reform: "The physicians are the natural lawyers for the poor and the social question comes to a large extent under their jurisdiction" ("Die Ärzte sind die natürlichen Anwälte der Armen und die soziale Frage fällt zu einem erheblichen Theil in ihre Jurisdiction"). ${ }^{68}$

Virchow's stance was in part a response to the backward conditions he encountered in the Prussian province of Upper Silesia when in early 1848 he visited the region as a member of a team of physicians dispatched there to survey a typhoid epidemic. ${ }^{69}$ Humboldtian medicine was uncongenial to the concerns of Virchow and like-minded reformers. Nothing is known of the mid-century politics of the Humboldtian medical geographers (although Mühry's later treatise Über die exacte Natur-Philosophie (1877) would seem to reflect liberal-conservative views) ${ }^{70}$ but one can appreciate that their emphasis on the climatological causes ${ }^{5}$ of typhoid, cholera and other diseases that periodically ravaged parts of Europe would have tended to direct reform energies away from an aggressive public health campaign. Humboldtian medicine pointed the finger of accusation at nature, and not at conditions of social deprivation, removing a burden of responsibility from the shoulders of the ruling élites. Mühry, in his Noso-Geographie, awarded the issue of public health barely one page. ${ }^{71}$ And the little he offered in terms of therapy, namely a change of location, could be afforded only by an affluent few, and was inapplicable to the underprivileged masses.

${ }^{67}$ K Finkenrath, Die Medizinalreform. Die Geschichte der ersten deutschen Standesbewegung von 1800-1850, Leipzig, A Barth, 1929; E H Ackerknecht, 'Beiträge zur Geschichte der Medizinalreform von 1848', Sudhoffs Archiv, 1932, 25: 61-109, 113-83. J Bleker, 'Die

Medizinalreformbewegung von 1848/49', Deutsches Ärzteblatt - Ärztliche Mitteilungen, 1976, 73: 2901-5, 2982-8.

${ }^{68} \mathbf{R}$ Virchow, "Was die "medicinische Reform" will', Die medicinische Reform, 10 July 1848, p. 2. The 52 issues have been photomechanically reproduced (Hildesheim, G Olms Verlag, 1975; also: Berlin, G Reimer Verlag, 1983).
${ }^{69}$ G B Risse, 'Rudolf Carl Virchow', in C C Gillispie (ed.), Dictionary of scientific biography, vol. 14, New York, C Scribner's Sons, 1981, p. 40. On Virchow's socio-political engagement see B A Boyd, Rudolf Virchow: the scientist as citizen, New York and London, Garland Publishing, 1991.

${ }^{70}$ A doctoral thesis on Adolf Mühry by Nicola Theus, Institute for the History of Medicine, Göttingen University, is in progress, and some clarity about Mühry's politics may result from this project.

${ }^{71}$ Mühry, op. cit., note 11 above, vol. 1, pp. 217-18. 


\section{Humboldtian Medicine}

One could argue ${ }^{72}$ that the orientation of the Humboldtian physicians towards physicalrather than social-environmental factors represented a deviation from the Humboldtian orthodoxy, in the sense that Humboldt himself was committed to various liberal, social causes. Examples of these were the rights of native Americans, the abolition of slavery and philosemitism. ${ }^{73}$ Yet there are good reasons for believing that Humboldt and the Humboldtians were in perfect accord with respect to medical geography. First, Humboldt himself subscribed to a physical-environmental aetiology of infectious diseases; in his Relation historique (3 vols, 1814-25) he ascribed malaria and, more hesitantly, yellow fever, to miasmas produced by particular conditions of temperature, humidity and vegetation. ${ }^{74}$ Second, Humboldt was the initiator of Berghaus' atlas and acted as a consultant editor during the years it was prepared; the atlas was in fact intended as a volume of illustration to accompany Kosmos. It is therefore highly improbable that the famous 'Planiglob zur Übersicht der geographischen Verbreitung der vornehmsten Krankheiten', which Berghausian map epitomized the physico-geographical approach to health and disease, would not have had Humboldt's sanction. ${ }^{75}$ Third, one should not over-estimate the strength of Humboldt's liberal commitments: he readily accommodated traditional and reactionary forces, whether those of the Spanish Crown or the Prussian Court. Bowen has argued that Humboldt's Kosmos, which was written during the decades that Humboldtian medicine took shape, had a politically impoverished view of physical geography because of contemporary, reactionary pressures. She contrasts Humboldt's liberal-conservative attitude with the radical stance of his contemporaries, August Comte, Karl Marx and John Stuart Mill. ${ }^{76}$

This interpretation of the failure of Humboldtian geography is more than pure speculation, supported as it is by Hirsch's averse reaction to Humboldtian medicine. In the introduction to his successful and highly regarded Handbuch, he distanced himself from his German predecessors and did not refer to them by name or book-title (he finally did in the much later second edition of the Handbuch), but collectively rejected their efforts as unsuccessful endeavours. He condemned any attempt to refer the distribution of diseases to laws borrowed from physical geography; the physical-environmental approach had failed, "because besides these influences the social conditions are an equally important factor, not merely for the spread or curtailment of diseases, but for their very origin". 77 Hirsch dedicated his book to "The London Epidemiological Society", for its promotion of public hygiene. Moreover, he emphasized his proximity to Virchow and put his book forward as a companion volume to the Handbuch der speciellen Pathologie und Therapie (6 vols, 1854-76), edited by Virchow, stressing that his work was of practical value and not merely of abstract scientific interest. ${ }^{78}$

\footnotetext{
$72 \ldots$ as do two of the anonymous referees of this paper.

${ }^{73}$ See for example Pratt, op. cit., note 16 above. An early discussion of Humboldt's philosemitism was by A Dove, 'Humboldt als Judengenoss', Im neuen Reich, 1871, 1: 377-81.

74 See notes 8 and 10 above.

${ }^{75}$ See Beck, op. cit., note 35 above.
}

\footnotetext{
${ }^{76}$ Bowen, op. cit., note 16 above.

77 A Hirsch, Handbuch der historischgeographischen Pathologie, vol. 1, Erlangen, Verlag F Enke, 1860, p. 3. See also H E Sigerist, 'Problems of historical-geographical pathology', Bull. Inst. Hist. Med. The Johns Hopkins University, 1933, 1: 10-18.

${ }^{78}$ Hirsch, ibid., pp. vii-viii.
} 


\section{Nicolaas Rupke}

\section{Conclusion}

The history of medical geography can not be adequately described by drawing a straight line from Finke to Hirsch. Several different, parallel traditions of medical geography existed. Based on a modest body of mainly German literature, not including Finke's Versuch and Hirsch's Handbuch, a Humboldtian genre of medical geography can be defined, distinct from both the British and the French approaches to medical geography. Its most prolific representative was the Göttingen physician Adolph Mühry. Humboldtian medicine was characterized by the fact that it used the concepts and representational structures of Humboldt's physical geography to describe the global distribution of human diseases. In its annexation of a modern science, Humboldtian medicine was part of the drive to place medicine on a scientific footing, yet it faded long before the germ theory of diseases led to a loss of interest in physical-environmental causes. The reason for this may have been that with its focus on the climatological causes of diseases, it missed the medical reform boat, the sail of which was set to the wind of social causes. 